\title{
MIREILLE SÉGUY, Mémoires du temps perdu. L'Élucidation médiévale et son remaniement dans l'imprimé de 1530
}

\section{Maria Colombo Timelli}

\section{OpenEdition}

\section{Journals}

\section{Édition électronique}

URL : https://journals.openedition.org/studifrancesi/32583

DOI : $10.4000 /$ studifrancesi.32583

ISSN : 2427-5856

Éditeur

Rosenberg \& Sellier

\section{Édition imprimée}

Date de publication : 1 août 2020

Pagination : 377

ISSN : 0039-2944

\section{Référence électronique}

Maria Colombo Timelli, « MireILle ségur, Mémoires du temps perdu. L'Élucidation médiévale et son remaniement dans l'imprimé de 1530 », Studi Francesi [En ligne], 191 (LXIV | II) | 2020, mis en ligne le 01 septembre 2020, consulté le 18 septembre 2021. URL : http://journals.openedition.org/studifrancesi/ 32583 ; DOI : https://doi.org/10.4000/studifrancesi.32583

Ce document a été généré automatiquement le 18 septembre 2021.

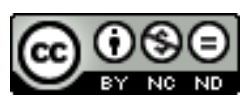

Studi Francesi è distribuita con Licenza Creative Commons Attribuzione - Non commerciale - Non opere derivate 4.0 Internazionale. 
MIREILLE SÉGUY, Mémoires du temps perdu. L'Élucidation médiévale et son remaniement dans l'imprimé de 1530

Maria Colombo Timelli 


\section{RÉFÉRENCE}

MIREILLE SÉGUY, Mémoires du temps perdu. L'Élucidation médiévale et son remaniement dans l’imprimé de 1530, “Études françaises” 55/1, 2019, pp. 161-184.

Ce qu'il est convenu d'appeler aujourd'hui le Perceval de 1530 ou Perceval le Galloys comprend la réécriture en prose du Conte du Graal de Chrétien de Troyes et de trois Continuations (à la seule exclusion de celle de Gerbert de Montreuil); publié une seule fois, à Paris, en 1530, cet ensemble déjà imposant contient-dans la plupart des exemplaires conservés - un cahier supplémentaire qu'occupe l'Élucidation de l'Hystoire du Graal, chapitre qui couvre de fait le contenu des deux pseudo-prologues dits Élucidation justement et Bliocadran. C'est au premier de ces deux pré-textes (édités récemment, versions en vers et en prose, par Hélène Bouget, Paris, 2018, cf. SF 189, 2009, p. 546; mais M.S. n'a pas pu en tenir compte) qu'est consacré cet article. Textesource et «traduction» en français de la Renaissance sont ici mis en regard, afin de déceler comment l'«étrangeté» de l'Élucidation en vers, avec ses allusions aux «gardes» dont le sens nous échappe encore en partie, est perçue et réécrite par le prosateur anonyme: selon la lecture de M.S., l'Élucidation médiévale aurait pour but de «remonter à l'origine de la fable arthurienne, [située] non à la cour du roi Arthur, mais dans un Autre Monde et un 'jadis' difficilement situables, et surtout désormais définitivement forclos» (p.174), alors que le «temps» de l'auteur de la prose serait «le temps chronologique de l'Histoire, qui s'applique autant à l'univers de fiction [...] qu'à celui de la composition du texte» (p. 180). 